\title{
MODEL PEMBELAJARAN TEMATIK INTEGRATIF MATEMATIKA TEMA OPERASI HITUNGAN DENGAN PENDEKATAN BAYANI, BURHANI, IRFANI.
}

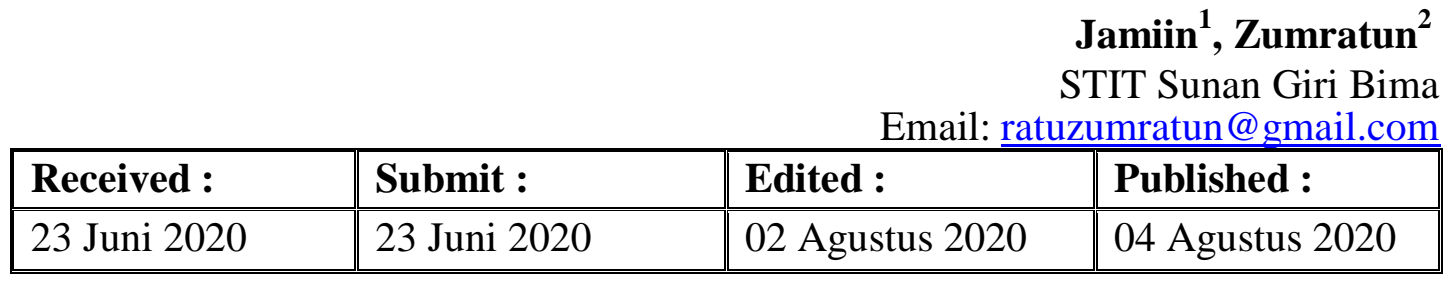

\begin{abstract}
Speaking on integrative thematic issues, it is inseparable from the 2013 curriculum. It is said so because the content or content of lessons in class presentations has been polished into one theme in which there are several subjects that have been integrated and one of them is the integration of Religion with Mathematics . The idea of integration of religious and general values is not a discourse to achieve academic sympathies, but rather an urgent need that must be carried out as a guide to existing education, given that education has been influenced by a strong dualism between the religious sciences and general sciences. In addition, the degradation of ethical values, morals and character of students also makes it a necessity for an institution to continue to teach all students about values without ignoring general lessons. So by presenting the integration of religious subjects and general subjects (mathematics), it is expected that all students have character values in themselves. This suggests that the implementation of Islamic education has a strategic portion in complementing the general education curriculum. That is, the learning process between general education and religion becomes the main process in creating human resources with the insight of science and technology, so that the added values obtained by students with the implementation of Islamic learning which certainly leads to the cultivation of morals, morals, and behavior of participants better students.
\end{abstract}

\section{Keywords: Learning Model, Integrative Thematic Learning, Numbers}

\begin{abstract}
ABSTRAK
Berbicara masalah tematik integratif, maka tidak terlepas dari kurikulum 2013. Dikatakan demikian karena isi atau muatan pelajaran dalam penyajian di kelas sudah dipoles menjadi satu dalam sebuah tema yang mana dalam tema tersebut terdapat beberapa mata pelajaran yang sudah terintegrasi dan salah satunya adalah integrasi Agama dengan Matematika. Gagasan integrasi nilai-nilai agama dan umum ini bukanlah sebuah wacana untuk meraih simpatik akademik, melainkan sebuah kebutuhan mendesak yang harus dijalankan sebagai pedoman pendidikan yang ada, mengingat pendidikan selama ini dipengaruhi oleh dualisme yang kental antara ilmuilmu agama dan ilmu-ilmu umum. Selain itu, degradasi nilai etika, moral dan karakter peserta didik juga menjadikan sebuah keharusan bagi sebuah lembaga agar terus mengajarkan kepada seluruh peserta didik tentang nilai (value) tanpa mengenyampingkan pelajaran umum. Sehingga dengan menghadirkan pengintegrasian mata pelajaran agama dan mata pelajaran umum (matematika), diharapkan semua peserta didik agar memiliki nilai karakter dalam diri pribadi mereka. Hal tersebut mengisyaratkan bahwa implementasi pendidikan Islami mendapat porsi yang strategi
\end{abstract}


dalam melengkapi kurikulum pendidikan umum. Artinya, proses pembelajaran antara pendidikan umum dan agama menjadi proses utama dalam menciptakan sumber daya manusia yang berwawasan imtaq dan iptek, sehingga nilai-nilai tambah yang didapatkan peserta didik dengan diterapkannya pembelajaran yang berwawasan Islami yang tentunya mengarah pada penanaman moral, akhlak, dan perilaku peserta didik yang lebih baik.

\section{Kata Kunci: Model Pembelajaran, Pembelajaran Tematik Integratif, Bilangan}

\section{PENDAHULUAN}

Matematika merupakan mata pelajaran yang menurut kebanyakan orang sangat sulit, terlebih bagi usia dasar, sehingga sangat banyak pesert didik yang merasa kesulitan untuk penyelesaian suatu problem ataupun soal-soal. Untuk memberikan pemahaman yang lebih, agar peserta didik dapat memahami matematika tersebut maka diperlukan tenaga pendidik yang profesional dan metode dan strategi yang tepat dalam penyampaiannya.

Pembelajaran matematika di sekolah dapat menggunakan pola pikir induktif maupun deduktif. Hal ini disesuaikan dengan topik bahasan dan tingkat pemahaman peserta didik. Secara umum pada tingkat SD, matematika didekati secara induktif terlebih dahulu, karena hal ini lebih memungkinkan peserta didik menangkap pengertian yang dimaksud.

Matematika sebagai bidang ilmu atau sebagai mata pelajaran yang dipelajari di setiap jenjang pendidikan, bahkan tanpa disadari matematika diperlukan orang dalam kehidupan sehari-hari. Di tingkat pendidikan dasar, mata pelajaran matematika bertujuan untuk mengembangkan kemampuan berkomunikasi dengan menggunakan bilangan dan simbolsimbol serta ketajaman penalaran sehingga dapat membantu memecahkan masalah matematika maupun permasalahan dalam kehidupan sehari-hari. Misalnya di SD ditekankan agar peserta didik mengenal, memahami serta mahir menggunakan bilangan dalam kaitannya dengan kebutuhan praktis dalam kehidupan sehari-hari.

Menurut Yohanes Surya dalam bukunya "Teori Bilangan: Seri Olimpiade Sains dan Matematika SD/MI”, menyatakan bahwa bilangan merupakan susunan dari angka-angka yang digunakan untuk menghitung jumlah dari sesuatu. Beliau juga menyatakan bahwa angka merupakan lambang atau simbol yang kita gunakan untuk menyusun sebuah bilangan, dan angka berjumlah 10 angka, yaitu $0,1,2,3,4,5,6,7,8$, dan $9{ }^{1}$

Dalam perhitungan bilangan tentang perpangkatan dan akar serta perhitungan bilangan campuran ini (perkalian, pembagian, penjumlahan dan pengurangan), akan diupayakan dengan mengintegrasikan nilai-nilai agama (pendidikan agama), ini dimaksudkan agar

\footnotetext{
${ }^{1}$ Yohanes Surya, Teori Bilangan: Seri Olimpiade Sains dan Matematika SD/MI, (Jakarta: PT. Kandel: 2016), 3.
} 
peserta didik tidak sekedar memahami tentang bagaimana cara menyelesaikan soal-soal, akan tetapi meraka juga memahami tentang manfaat dan tujuan pelajaran matematika dalam kaitannya dengan kehidupan sehari-hari seperti adanya nilai kejujuran karena memang ilmu matematika merupakan ilmu pasti, melatih ketelitian, berpikir logis, analisis dan manfaat lainnya. Olehnya demikian, penulisan ini berupaya mengintegrasikan mata pelajaran matematika tersebut dalam pembelajaran PAI.

\section{MODEL PEMBELAJARAN}

Ada beberapa pendapat yang menjelaskan tentang model pembelajaran diantaranya ialah Joyce, Weil dan Calhoun menjelaskan bahwa model pembelajaran integrasi merupakan gambaran suatu lingkup pembelajaran, yang juga meliputi perilaku kita sebagai guru saat model tersebut diterapkan. ${ }^{2}$ Pendapat lain oleh Joyce menjelaskan bahwa secara lebih spesifik, model pembelajaran adalah suatu perencanaan atau pola yang digunakan sebagai pedoman dalam merencpeserta didikan pembelajaran di kelas atau pembelajaran dalam tutorial dan untuk menentukan perangkat-perangkat pembelajaran termasuk di dalamnya buku-buku, film, komputer, kurikulum, dan lain sebgainya. ${ }^{3}$ Di buku lain Joyce dan Weil menyatakan bahwa model pembelajaran integrasi dapat dijadikan pola pilihan, artinya para guru boleh memilih model pembelajaran yang sesuai dan efisien untuk mencapai tujuan pendidikannya. ${ }^{4}$

Menurut Soekanto, dkk., berpendapat bahwa model pembelajaran integrasi adalah "kerangka konseptual yang melukiskan prosedur yang sistematis dalam mengorganisasikan pengalaman belajar untuk mencapai tujuan belajar tertentu, dan berfungsi sebagai pedoman bagi para perancang pembelajaran dan para pengajar dalam merencpeserta didikan aktivitas belajar mengajar". 5 Sementara menurut Mamat SB, dkk. Memaknai bahwa pembelajaran integrasi merupakan pembelajaran terpadu, dengan mengelola pembelajaran yang diintegrasikan materi dari beberapa mata pelajaran dalam satu topik pembicaraan yang disebut tema. ${ }^{6}$

${ }^{2}$ Bruce Joice, Marhsa Weil, dan Emily Calhoun, Models of Teaching:Model-model Pengajaran, (cet. VIII , Yogyakarta: Pustaka Pelajar, 2009), 30.

${ }^{3}$ Bruce Joice, Marhsa Weil, dan Emily Calhoun, Models of Teaching:Model-model Pengajaran, 30.

${ }^{4}$ Rusman, Model-Model Pembelajaran: Mengembangkan Profesioanlisme Guru, (Jakarta: PT. Raja Grafindo Persada), 133.

${ }^{5}$ Trianto, Desain Pembelajaran, 141.

${ }^{6}$ Andi Prastowo, Pengembangan Bahan Ajar Tematik: Tinjauan Teoritis dan Praktik, (Jakarta: Kencana Prenadamedia Group, 2014), 54. 
Berdasarkan penjelasan tersebut di atas, dapat dipahami bahwa istilah model pembelajaran integrasi mempunyai makna yang lebih luas dibandingkan denga strategi, metode atau prosedur pembelajaran, sementara model pembelajaran itu sendiri mempunyai empat ciri khusus sebagaimana yang dijelaskan oleh Rusman yakni:

1. Rasional teoritis logis yang disusun oleh para pencipta atau pengembangny,

2. Landasan pemikiran tentang apa dan bagaimana peserta didik belajar (tujuan pembelajaran yang akan dicapai),

3. Tingkah laku mengajar yang dibutuhkan agar model tersebut dapat dilakspeserta didikan dengan berhasil, dan

4. Lingkungan belajar yang dibutuhkan agar tujuan pembelajaran tersebut dapat tercapai. ${ }^{7}$

\section{PEMBELAJARAN TEMATIK INTEGRATIF}

Berbicara tentang tematik integratif, maka tidak terlepas dari kurikulum 2013. Hal ini dikarenakan kurikulum 2013 bersifat tematik-integratif yang mengambil pokok bahasan pelajaran berdasarkan tema dengan menggabungkan beberapa pelajaran menjadi satu. Selain itu, kurikulum 2013 juga menekankan pada dimensi pedagogik modern dalam pembelajaran, yaitu pendekatan ilmiah (scientific approach). Pendekatan ini lebih menitik beratkan pada kegiatan mengamati, menanya, menalar, mencoba, dan membentuk jejaring. Model pembelajaran tematik integratif atau terpadu (PTP) atau dikenal dengan integrated thematic instructio (ITI) menjadi model pembelajaran utama yang harus dikembangkan guru untuk mengimplementasikan kurikulum 2013.

Model pembelajaran ini sebenarnya telah lama ada. Model pembelajaran tematik integratif pertama kali dikembangkan pada tahun 1970-an. PTP diyakini para ahli pendidikan sebagai salah satu model pengajaran yang efektif (highly effective teaching model). Kehandalannya didasari kenyataan bahwa pembelajaran tematik integratif mampu mewadahi dan menyentuh secara menyeluruh ketiga ranah sekaligus yakni ranah emosi, fisik dan akademik peserta didik atau yang kita kenal sekarang ini yakni: ranah kognitif, afektif, dan psikomotorik. Hal ini didukung oleh para pengikut aliran psikologi yang berpandangan bahwa proses belajar terjadi pada latar kognitif maupun sosial. Lebih lanjut dinyatakan oleh Jean Piaget melalui teori perkembangan kognitifnya dan menyatakan bahwa setiap peserta didik memilik cara tersendiri dalam menginterpretasikan dan beradaptasi dengan lingkungannya. ${ }^{8}$

\footnotetext{
${ }^{7}$ Trianto, Desain Pembelajaran, 142-143.

${ }^{8}$ Desmita, Psikologi Perkembangan Peserta Didik, (Bandung: PT. Remaja Rosda Karya, 2015), 139142.
} 
Pembelajaran tematik integratif secara empirik sudah menunjukkan keberhasilannya dalam memacu percepatan dan meningkatkan memori peserta didik (enhance learning and increace long-term memory capabilities of leaners) untuk waktu yang panjang. Dalam sejarah perkembangannya di era 70-an, pembelajaran tematik integratif (integrated thematic instruction) dimaksudkan untuk peserta didik-peserta didik berbakat dan bertalenta (gifted and talented), cerdas, pada perluasan belajar, dan yang belajar cepat.

Menurut Depdiknas yang dimaksud dengan pembelajaran tematik pada dasarnya adalah merupakan model pembelajaran terpadu dengan menggunakan tema untuk mengaitkan beberapa mata pelajaran sehingga dapat memberikan pengalaman belajar yang bermakna kepada peserta didik. ${ }^{9}$ Sementara Kemendikbud menjelaskan bahwa pembelajaran tematikintegratif merupakan pendekatan pembelajaran yang mengintegrasikan berbagai kompetensi dari berbagai mata pelajaran ke dalam berbagai tema. Pengintegrasian tersebut dilakukan dalam dua hal, yaitu integrasi sikap, keterampilan, dan pengetahuan dalam proses pembelajaran dan integrasi berbagai konsep dasar yang berkaitan. ${ }^{10}$

Dari pendapat tersebut di atas, dapat dipahami bahwa pembelajaran tematik integratif merupakan strategi pembelajaran yang dirancang oleh seorang pendidik untuk diterapkan kepada peserta didik dalam proses kegiatan belajar mengajar di kelas yang disajikan berdasarkan tema-tema tertentu sesuai analisis kebutuhan peserta didik. Pembelajaran tematik integratif juga memberikan keluasan bagi peserta didik untuk lebih aktif, inovatif, analisis, serta memunculkan ide dan gagasan mereka melalui pendidikan.

\section{Konsep Bilangan}

Bilangan adalah suatu konsep matematika yang digunakan untuk pencacahan dan pengukuran. Simbol ataupun lambang yang digunakan untuk mewakili suatu bilangan disebut sebagai angka atau lambang bilangan. Dalam matematika, konsep bilangan selama bertahuntahun lamanya telah diperluas untuk meliputi bilangan nol, bilangan negatif, bilangan rasional, bilangan irasional, dan bilangan kompleks. Bilangan adalah suatu ide yang bersifat abstrak yang akan memberikan keterangan mengenai banyaknya suatu kumpulan benda. ${ }^{11}$ Secara umum, bilangan itu sendiri bermacam-macam jenisnya antara lain: bilangan bulat (positif dan negatif), bilangan cacah, bilangan prima, dan bilangan asli.

\footnotetext{
${ }^{9}$ Trianto, Model Pembelajaran Terpadu, (Jakarta: Bumi Aksara, 2011), 147.

${ }^{10}$ Depdiknas, Strategi Pembelajaran yang Mengaktifkan Siswa, (Jakarta: Depdiknas, tt), th.

${ }^{11}$ Fadhil darmawi, Makalah Matematika Bilangan, https:// fadhildarmawi. blogspot. com/ 2014/ 06/ makalah-matematika-bilangan.html, 13/3/2020, 20.24 wita.
} 
Bilangan pada awalnya hanya dipergunakan untuk mengingat jumlah, namun dalam perkembangannya setelah para pakar matematika menambahkan perbendaharaan simbol dan kata-kata yang tepat untuk mendefinisikan bilangan, maka matematika menjadi hal yang sangat penting bagi kehidupan dan tak bisa kita pungkiri bahwa dalam kehidupan sehari-hari, kita akan dihadapkan dengan yang namanya bilangan, karena bilangan selalu dibutuhkan baik dalam teknologi, sains, ekonomi, ataupun dalam dunia musik, filosofi dan hiburan serta banyak aspek kehidupan lainnya. ${ }^{12}$

Menurut Yohanes Surya dalam bukunya "Teori Bilangan: Seri Olimpiade Sains dan Matematika SD/MI", menyatakan bahwa bilangan merupakan susunan dari angka-angka yang digunakan untuk menghitung jumlah dari sesuatu. Beliau juga menyatakan bahwa angka merupakan lambang atau simbol yang kita gunakan untuk menyusun sebuah bilangan, dan angka berjumlah 10 angka, yaitu $0,1,2,3,4,5,6,7,8$, dan $9 .{ }^{13}$ Bilangan adalah suatu idea. Sifatnya abstrak. Bilangan bukan simbol ataupun lambang dan bukan pula lambang bilangan. Bilangan memberikan keterangan mengenai banyaknya anggota suatu himpunan. (Sumber: Ensiklopedia Matematika, 1998). ${ }^{14}$ Sementara menurut kamus Matematika menyatakan bahwa "bilangan merupakan suatu ukuran dari besaran, tetapi dipakai dalam suatu cara abstrak tanpa menghubungkannya dengan berapa banyak atau pengukurannya. ${ }^{15}$

\section{Paradigma Integrasi Matematika Dengan Agama}

Salah satu alasan dan tujuan pentingnya integralisasi pendidikan agama pada dasarnya membantu mengembangkan kemahiran berinteraksi pada tahapan yang lebih tinggi serta meningkatkan kebersamaan dan kekompakan interaksi sehingga peserta didik memiliki nilai kepribadian dan rasa sosial yang tinggi. Pada dasarnya mengintegrasikan mata pelajaran agama adalah untuk menanamkan nilai-nilai keIslaman lebih dini terutama ditingkat dasar/MI. Tujuan pendidikan nilai tidak dapat tercapai tanpa aturan-aturan, indoktrinasi atau pertimbangan prinsip-prisnip belajar. Namun sebaliknya, dorongan moral komponen pembentukan struktur itu sangat penting. Oleh karena itu, pendidik seharusnya tidak hanya sekedar membekali peserta didik dengan pengetahuan tentang tujuan serta analisis dari hubungan antara tujuan dengan alat, akan tetapi pendidikan lebih pada penanaman nilai-nilai spiritual keagamaan.

${ }^{12}$ Abdul Raiz, Bulangan Bulat: Teori Bilangan, https:// abdulraiz-raish. blogspot. com/ 2015/ 01/ bilangan-bulat-teori-bilangan.html, 13/3/2020, 20.24 Wita.

${ }^{13}$ Yohanes Surya, Teori Bilangan: Seri Olimpiade Sains dan Matematika SD/MI, (Jakarta: PT. Kandel, 2016), 3.

${ }^{14}$ Arso, dkk, Modul Pendidikan Matematika 1, (Jakarta: Universitas Terbuka, 2004), th.

${ }^{15}$ Roy Hollands, Kamus Matematika, (Jakarta: Erlangga 1995), 15. 
Matematika sebagai bidang ilmu atau sebagai mata pelajaran yang dipelajari di setiap jenjang pendidikan, bahkan tanpa disadari matematika diperlukan orang dalam kehidupan sehari-hari. Di tingkat pendidikan dasar, mata pelajaran matematika bertujuan untuk mengembangkan kemampuan berkomunikasi dengan menggunakan bilangan dan simbolsimbol serta ketajaman penalaran sehingga dapat membantu memecahkan masalah matematika maupun permasalahan dalam kehidupan sehari-hari. Misalnya di SD ditekankan agar peserta didik mengenal, memahami serta mahir menggunakan bilangan dalam kaitannya dengan kebutuhan praktis dalam kehidupan sehari-hari, akan tetapi tujuan mengintegrasikan adalah agar peserta didik tidak sekedar memahami tentang bagaimana cara berhitung namun, mereka juga akan ditanamkan nilai-nilai keagamaan, sehinngg dengan nilai tersebut peserta didik dapat memiliki kecakapan kognitif sekaligus kecakapan spiritual sebagai potensi dasar dalam pembentukan diri yang baik. Secara fisik, ranah kognitif akan menumbuhkan kemajuan IQ (Intelligence Quotient). Sedangkan potensi psikis dan spiritual, yang ada dalam ranah afektif, akan menumbuhkan EQ (Emotional Quotient) dan SQ (Spiritual Quotient). Pertumbuhan yang seimbang antara IQ, EQ, dan SQ diyakini akan membawa peserta didik pada keadaan aman dan nyaman dalam mengikuti pembelajaran.

Menurut Ali Asraf pentingnya integrasi pendidikan nilai tersebut menjadi satu kerangka normatif dalam merumuskan tujuan pendidikan Islam:

1. Mengambangkan wawasan spiritual yang semakin mendalam dan mengembangkan pemahaman rasional mengenai Islam dalam konteks kehidupan modern,

2. Membekali peserta didik didik dengan berbagai kemampuan pengetahuan dan kebajikan, baik pengetahuan praktis, kesejahteraan, lingkungan sosial, dan pembangunan nasional,

3. Mengembangkan kemampuan pada diri peserta didik didik untuk menghargai dan membenarkan superioritas komparatif kebudayaan dan peradaban Islam di atas semua kebudayaan lain,

4. Memperbaiki dorongan emosi melalui pengalaman imajinatif, sehingga kemampuan kreatif dapat berkembang dan berfungsi mengetahui norma-norma Islam yang benar dan yang salah,

5. Membantu peserta didik yang sedang tumbuh untuk belajar berpikir secara logis dan membimbing proses pemikirannya dengan berpijak pada hipotesis dan konsep-konsep pengetahuan yang dituntut, dan

6. Mengembangkan, menghaluskan, dan memperdalam kemampuan komunikasi dalam bahasa tulis dan bahasa latin (asing). ${ }^{16}$

Contoh mengintegasikan mata pelajaran matematika (pengkuadratan, perkalian, pembagian, penjumlahan dan pengurangan) dengan agama antara lain:

1. Memahami sikap tawaddu' kepada Allah dengan konsep perpangkatan.

${ }^{16}$ Ali M dan Luluk Y. R., PAradigma Pendidikan Universal di Era Modern dan Post-Modern; Mencarai "Visi Baru" atas "Realitas Baru” Pendidikan Kita, 2004, 267-274. 
2. Memahami adanya persamaan kedudukan manusia dimata Allah kaitannya dengan sistem persamaan linear baik satu peubah maupun dua peubah.

3. Memahami tentang keberadaan manusia di muka bumi Allah dengan konsep geometri.

4. Memahami konsep ketelitian dengan konsep operasi hitung bilangan campuran. Dalam hal ini kaitannya dengan perintah Allah SWT. akan pentingnya kita bersodaqoh, sebagai gambaran tentang keutamaan dan tujuan bersodaqoh adalah seperti berikut:

a. $15: 3=5$, ini bermakna "ketika kita mau berbagi maka, akan timbul rasa solidaritas dan kepedulian terhadap sesama".

b. 7 × $3=21$, ini maksudnya ialah "seseorang yang menggunakan hartanya dijalan Allah, maka bagi dirinya akan dikalikan pahalanya”. Sebenarnya dalam Al-qur'an tidak ada perkalian karena secara kualitas amal bukan bilangan, akan tetapi ini sebagai sebuah penjelasan tentang pahala orang yang bersodaqoh.

c. $11-9=2$, ini mengandung makna bahwa "saat seseorang mengeluarkan hartanya untuk bersodaqoh/kejalan Allah, maka sebenarnya harta yang disodaqohkan/dibelanjakan dijalan Allah tersebut tidaklah akan berkurang".

d. $13+7=20$, ini bermakna bahwa "dari harta yang kita keluarkan tadi sesungguhnya secara kasat mata itu memang terlihat berkurang, padahal sesungguhnya harta kita akan bertambah dimata Allah".

\section{Operasi Hitung Bilangan Dalam Al-Qur'an}

Di dalam Al-qur'an relasi dapat membandingkan antara suatu bilangan dengan bilangan yang lain. Adanya bilangan dan relasi belum lengkap, jika tidak dapat melakukan suatu aksi pada pasangan bilangan yang diberikan. Melakukan aksi pada pasangan bilangan dapat dinamakan operasi. Operasi yang paling sederhana adalah operasi hitung dasar bilangan. Operasi hitug dasar bilangan meliputi penjumlahan (+), pengurangan (-), perkalian (x), dan pembagian (:). Selain berbicara bilangan dan relasi bilangan, ternyata al-Qur'an juga berbicara tentang operasi hitung dasar pada bilangan. Operasi hitung dasar pada bilangan yang disebutkan dalam al-Qur'an adalah operasi penjumlahan, pengurangan, dan pembagian. ${ }^{17}$ Sementara menurut kamus Matematika menyatakan bahwa "bilangan merupakan suatu ukuran dari besaran, tetapi dipakai dalam suatu cara abstrak tanpa menghubungkannya dengan berapa banyak atau pengukurannya. ${ }^{18}$ Press), 79.

17 Abdussakir, Matematika 1: Kajian Integratif Matematika dan Al-Qur'an, (Malang: UIN Malang

${ }^{18}$ Roy Hollands, Kamus Matematika, (Jakarta: Erlangga 1995), 15. 
Untuk menjelaskan tentang operasi hitung bilangan dalam Al-qur'an, maka akan dijelaskan dengan merujuk pada firman Allah tentang perintah bersodaqoh dan sebelum menyelesaikan soal-soal tersebut ada empat prinsip perkalian bilangan yang harus dipahami yang semua itu tentunya pasti akan masuk pada operasi pembagian, pengurangan, penjumlahan, dan perkalian itu sendiri seperti berikut:

\section{Operasi Pembagian}

Dalam al-Qur'an surat Al-Hadid ayat 7 Allah SWT. Berfirman:

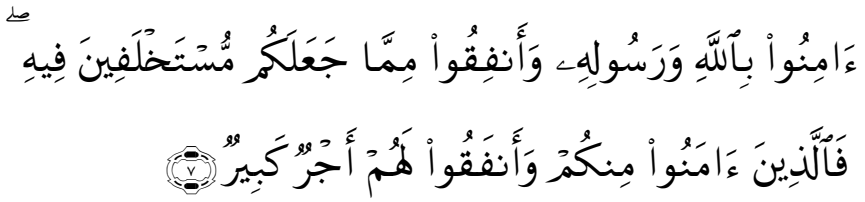

Terjemahan :

Berimanlah kamu kepada Allah dan Rasul-Nya dan nafkahkanlah sebagian dari hartamu yang Allah telah menjadikan kamu menguasainya[1456]. Maka orangorang yang beriman di antara kamu dan menafkahkan (sebagian) dari hartanya memperoleh pahala yang besar.

[1456] Yang dimaksud dengan menguasai di sini ialah penguasaan yang bukan secara mutlak. hak milik pada hakikatnya adalah pada Allah. manusia menafkahkan hartanya itu haruslah menurut hukum-hukum yang telah disyariatkan Allah. karena itu tidaklah boleh kikir dan boros.

Al Qurthubi rahimahullah menjelaskan, "Ayat ini merupakan dalil bahwa pada hakekatnya harta itu milik Allah. Hamba tidaklah memiliki apa-apa melainkan apa yang Allah ridhoi. Siapa saja yang menginfakkan harta pada jalan Allah, maka itu sama halnya dengan seseorang yang mengeluarkan harta orang lain dengan seizinnya. Dari situ, ia akan mendapatkan pahala yang melimpah dan amat banyak."Al Qurtubhi rahimahullah sekali lagi mengatakan, Riwayat ini adalah riwayat yang shahih "Hal ini menunjukkan bahwa harta kalian pada hakikatnya bukanlah milik kalian. Kalian hanyalah bertindak sebagai wakil atau pengganti dari pemilik harta yang sebenarnya. Oleh karena itu, manfaatkanlah kesempatan yang ada dengan sebaik-baiknya untuk memanfaatkan harta tersebut di jalan yang benar sebelum harta tersebut hilang dan berpindah pada orang-orang setelah kalian. ${ }^{19}$

Secara matematis pembagian akan dapat dijelaskan dengan unsur bilangan, yakni dengan melakukan perhitungan tentang pembagian bilangan matematika misalnya seperti contoh soal berikut:

\footnotetext{
${ }^{19}$ Muassasah Qurthubah, Tafsir Al Qur'an Al 'Azhim, Ibnu Katsir, Tafsir surat Al Hadiid ayat 1113/414415, Riwayat ini adalah riwayat yang shahih.
} 
Pada pengurangan bilangan ada empat prinsip atau bentuk soal yang dapat dikerjakan diantaranya:
a. $15: 3=5$
b. $21:(-3)=-7$
c. $(-27): 9=-3$
d. $(-35):(-5)=7$

Keterangan:

1) Prinsip pertama yakni (positif) dibagi (positif), hasilnya positif.

2) Prinsip kedua (positif) dibagi (negatif), hasilnya negatif.

3) Prinsip ketiga (negatif) dibagi (positif), hasilnya negatif.

4) Prinsip keempat (negatif) dibagi (negatif), hasilnya positif.

\section{Operasi Pengurangan}

Allah berfirman dalam QS. An-Nahl: 96

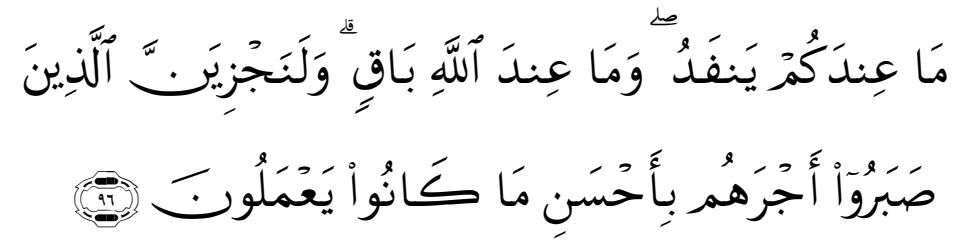

Terjemahan :

Apa yang di sisimu akan lenyap, dan apa yang ada di sisi Allah adalah kekal. dan Sesungguhnya Kami akan memberi Balasan kepada orang-orang yang sabar dengan pahala yang lebih baik dari apa yang telah mereka kerjakan.

Dalam hadits dijelaskan bahwa sedekah tidaklah mengurangi harta. Nabi shallallahu 'alaihi wa sallam bersabda:

Artinya: "Sedekah tidaklah mengurangi harta."

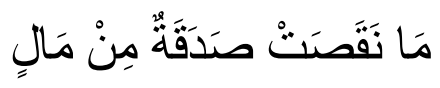

Makna hadits di atas sebagaimana dijelaskan oleh Yahya bin Syarf An Nawawi rahimahullah ada dua penafsiran:

a. Harta tersebut akan diberkahi dan akan dihilangkan berbagai dampak bahaya padanya.

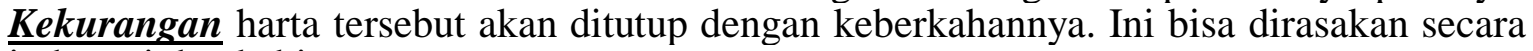
inderawi dan kebiasaan.

b. Walaupun secara bentuk harta tersebut berkurang, namun kekurangan tadi akan ditutup dengan pahala di sisi Allah dan akan terus ditambah dengan kelipatan yang amat banyak. ${ }^{20}$

${ }^{20}$ Al Minhaj Syarh Shahih Muslim, 16/141, Dar Ihya' At Turots Al 'Arobi, cet. Ke II, 1392. 
Pada pengurangan bilangan ada lima prinsip atau bentuk soal yang dapat dilakukan yakni diantaranya:

1) $13-5=8$

2) $15-17=-2$

3) $(-23)-7=-30$

4) $9-(-11)=20$

5) $(-11)-(-17)=6$

Keterangan:

a) Prinsip pertama (positif) dikurangi (positif), hasilnya positif.

b) Prinsip kedua (positif terkecil) dikurangi (positif terbesar), hasilnya negatif.

c) Prinsip ketiga (negatif) dikurangi (negatif), hasilnya negatif.

d) Prinsip keempat (positif) dikurangi (negatif), hasilnya positif.

e) Prinsip kelima (negatif) dikurangi (negatif), hasilnya positif.

\section{Operasi Penjumlahan}

Allah SWT. Berfirman dalam QS. Al-Baqarah: 245

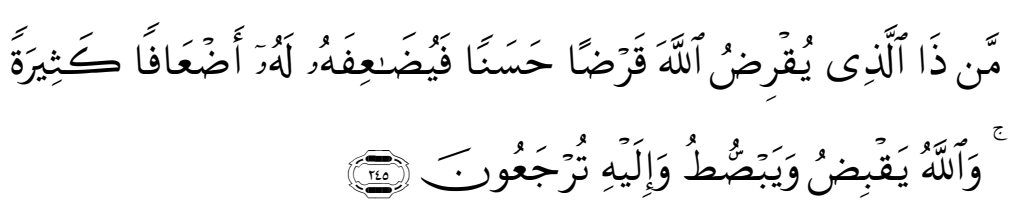

Terjemahan :

Siapakah yang mau memberi pinjaman kepada Allah, pinjaman yang baik (menafkahkan hartanya di jalan Allah), Maka Allah akan meperlipat gandakan pembayaran kepadanya dengan lipat ganda yang banyak. dan Allah menyempitkan dan melapangkan (rezki) dan kepada-Nya-lah kamu dikembalikan.

Pada penjumlahan bilangan ada empat prinsip yang dapat diselesaikan diantaranya:

a. $9+7=16$

b. $11+(-3)=8$

c. $(-13)+5=-8$

d. $(-15)+(-21)=-36$

Keterangan:

1) Prinsip pertama (positif) ditambah (positif), hasilnya positif.

2) Prinsip kedua (positif) ditambah (negatif), hasilnya psotif.

3) Postif ketiga (negatif) ditambah (positif), hasilnya negatif.

4) Prinsip keempat (negatif) ditambah (negatif), hasilnya negatif 


\section{Operasi Perkalian}

Sebenarnya didalam Al-Qur'an tidak dijelaskan tentang perkalian, namun di dalam sebuah ayat yang menjelaskan tentang perkalian meskipun perkalian tersebut tidak bisa dimaknai sebagai operasi perkalian bilangan, karena secara kualitas amal bukan bilangan. ${ }^{21}$ Untuk memahami hal tersebut mari perhatikan firman Allah SWT. Dalam Al-Qur'an Surat al-An'aam: 160 berikut:

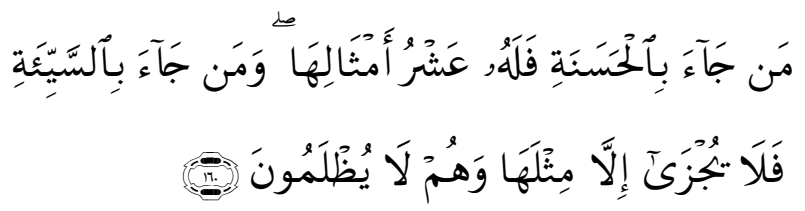

Terjemahan : Barangsiapa membawa amal yang baik, Maka baginya (pahala) sepuluh kali lipat amalnya; dan Barangsiapa yang membawa perbuatan jahat Maka Dia tidak diberi pembalasan melainkan seimbang dengan kejahatannya, sedang mereka sedikitpun tidak dianiaya (dirugikan).

Dari ayat tersebut dapat diketahui, bahwasanya setiap amal manusia akan dilipatgandakan sepuluh kali lipat. Artinya, sebesar apapun kebaikan yang dilakukan oleh seorang hamba. Maka, baginya pahala yang berlipat ganda.

Pada operasi perkalian terdapat keterkaitan antara perkalian dengan pembagian, dan perkalian dengan penjumlahan. Untuk lebih jelasnya, perhatikan contoh soal berikut:

a. Perkalian dengan pembagian

1) $5 \times 7=35 \Rightarrow 35: 7=5$ atau $35: 5=7$.

2) $3 \times(-7)=-21 \Rightarrow(-21):(-7)=3$ atau $(-21): 3=-7$

3) $(-2) \times 7=-14=>(-14): 7=-2$ atau $(-14):(-2)=7$

4) $(-9) \times(-5)=45 \Rightarrow 45:(-5)=-9$ atau $45:(-9)=-5$

Seperti yang dijelaskan di atas gunakan prinsip perkalian berikut untuk memahami penyelesaiannya:

b. Perkalian dengan penjumlahan

1) $5 \times 12=60$, atau $5 \times 12=12+12+12+12+12=60$.

\section{Perspektif Integrasi Tentang Bilangan \\ Pendekatan Bayani}

${ }^{21}$ Abdussakir, Matematika 1: Kajian Integratif Matematika dan Al-Qur'an, (Malang: UIN Malang Press), 82. 
Pendekatan bayani dalam pembelajaran matematika di sekolah yaitu proses pengintegrasian ilmu keislaman terhadap ilmu matematika dengan merujuk kepada penerjemahan makna dari ayat-ayat Al-Qur'an yang berkaitan dengan objek kajian/materi pembelajaran matematika. Jadi, pendekatan bayani ini hanya memfungsikan akal sebagai instrumen untuk mengetahui, mengahafal, dan memahami makna-makna ayat Al-Qur'an yang berkaitan dengan matematika. Pendekatan bayani dalam pembelajaran operasi hitung bilangan yaitu menjelaskan tentang perhitungan yang ada dalam Al-Qur'an baik berupa perkalian, pembagian, pengurangan maupun pembagian.

Pendekatan bayani dipandang dapat mengintegrasikan matematika dengan ke-Islaman dalam pembelajaran, melalui pendekatan ini, mengarahkan pemikiran peserta didik terkait dengan keterpaduan matematika dan agama dalam ilmu pengetahuan. Akan tetapi, kelemahan dari pendekekatan bayani yaitu pemahaman yang didapatkan hanya sebatas pengertianpengertian (teoritis) yang bersifat kaku dan tetap, tidak ada proses akal yang memaknai dan menarik makna lebih dalam materi yang dipelajari. Sehingga, pengetahuan yang didapat peserta didik hanya besifat konseptual bukan pada fungsional (pemanfaatan). Artinya, proses pengintegrasian tidak cukup hanya dengan pendekatan bayani tetapi harus ada pendekatan yang bisa menggali dan menguraikan makna dan manfaat dibalik fakta yang ada (burhani) serta pendekatan yang memposisikan akal berfungsi untuk menganalisis, mengsintesis dan mengevaluasi dari fakta-fakta dalam rangka memperoleh esensi dan manfaat yang kemudian kebenaran yang didapat diaplikasikan kepada kehiudpan nyata.

\section{a. Firman Allah swt. dalam Al-Qur'an At-Taubah: 36}

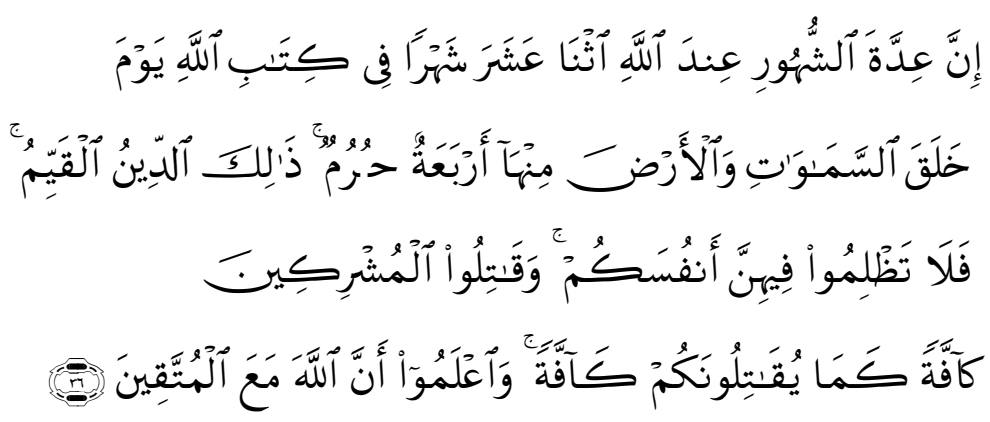

Terjemahan :

Sesungguhnya bilangan bulan pada sisi Allah adalah dua belas bulan, dalam ketetapan Allah di waktu Dia menciptakan langit dan bumi, di antaranya empat bulan haram[640]. Itulah (ketetapan) agama yang lurus, Maka janganlah kamu Menganiaya diri[641] kamu dalam bulan yang empat itu, dan perangilah kaum musyrikin itu semuanya sebagaimana merekapun memerangi kamu semuanya, dan ketahuilah bahwasanya Allah beserta orang-orang yang bertakwa.

[640] Maksudnya antara lain Ialah: bulan Haram (bulan Zulkaidah, Zulhijjah, Muharram dan Rajab), tanah Haram (Mekah) dan ihram. 
[641] Maksudnya janganlah kamu Menganiaya dirimu dengan mengerjakan perbuatan yang dilarang, seperti melanggar kehormatan bulan itu dengan Mengadakan peperangan.

Jadi, dapat diketahui bahwa operasi bilangan dan waktu (tentang perihal-perihal bulan kalender) juga sudah dijelaskan oleh Allah swt. dalam Al-Qur'an seperti yang dibahas di atas, terkait ayat tersebut dijelaskan bahwa bilangan bulan yang berjumlah 12 bulan itu sama dengan satu tahun, kemudian dikurangi oleh empat bulan haram yakni bulan Zulkaidah, Zulhijjah, Muharam, dan bulan Rajab yang semua itu ditetapkan oleh Allah sendiri sejak langit dan bumi diciptakan.

\section{b. Hadist Rosulullah}

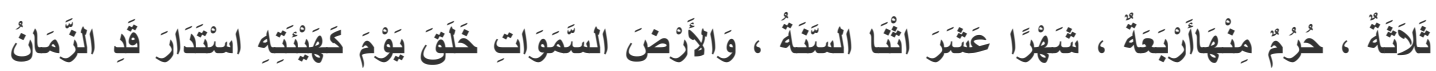

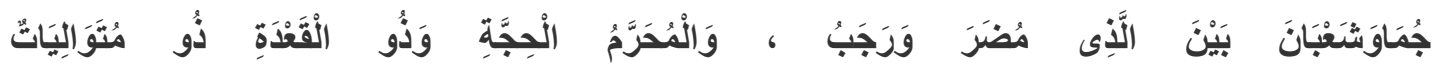
"Sesungguhnya zaman ini telah berjalan (berputar) sebagaimana perjalanan awalnya ketika Allah menciptakan langit dan bumi, yang mana satu tahun itu ada dua belas bulan. Diantaranya ada empat bulan haram, tiga bulan yang (letaknya) berurutan, yaitu Dzul Qa'dah, Dzul Hijjah, dan Muharram, kemudian bulan Rajab Mudhar yang berada diantara Jumada (Akhir) dan Sya'ban." (HR. Al Bukhari: 4385 dan Muslim:(1679).

\section{Pendekatan Burhani}

Pendekatan burhani dalam pembelajaran matematika di sekolah yaitu mengintegrasikan ilmu keislaman terhadap ilmu matematika yang tidak hanya merujuk pada makna ayat-ayat Al-Qur'an dan cara berhitung saja, melainkan peninjauan lebih spesifik dan mendalam dengan akal (penalaran, pemaknaan, dan analisis) untuk membuktikan makna-makna (tekstual) yang ada sehingga melahirkan pengertian-pengertian baru yang substansial serta memberikan pemahaman terkait manfaat-manfaat yang dapat diaplikasikan dalam kehidupan nyata.

Pendekatan banyani pada pembelajaran mengenai operasi hitung bilangan, sebenarnya penjelasan tentang perhitungan bilangan (penjumlahan, pengurangan, pembagian, dan perkalian) itu sudah tertera dengan jelas di dalam Al-Qur'an dan semua itu memiliki keterkaitan langsung dengan segala aktifitas manusia khususnya peserta didik yang menjadi topik dasar dalam penerapan dan penanaman nilai-nilai realigi sedari dini, dan hal itu dapat dilakukan baik berupa penggunaan kalender, jam digital/analog, alat timbangan, penggaris, 
speedometer, kebiasaan mandi 2-3 kali, sampai pada penggunaan uang yang lebih dekat dengan keseharian mereka. Hal tersebut seperti yang tertera dalam surah At-Taubah: 36 di atas.

Pentingnya pendekatan burhani dalam matematika yaitu mengajarkan kepada peserta didik untuk tidak hanya mengetahui pada batasan pengertian-pengertian (teori) tetapi bagaimana mengaplikasikan teori tersebut dalam bentuk perbuatan, perilaku, dan kebiasaankebiasaan yang menopang kesejahteraan kehidupan manusia. Akan tetapi, pendekatan burhani juga tidak cukup untuk memberikan pemahaman sekaligus pengaplikasian materi matematika, peserta didik juga harus dapat diberikan pengetahuan pada tatanan nilai-nilai yang terkadung didalamnya. Sehingga, pemahaman peserta didik akan berimbang antara kognitif (teori), afektif (sikap/karakter), psikomotorik (keterampilan), dan spiritual. Singkatnya, pendekatan yang dapat digunakan untuk sampai pada tahapan itu yaitu pendekatan irfani.

\section{Pendekatan Irfani}

Paradigma integratif dengan pendekatan irfani dalam pembelajaran matematika bertujuan untuk memberikan pengetahuan tentang operasi hitung bilangan kepada peserta didik dengan mengacu pada perspektif matematika dan ayat-ayat Al-Qur'an serta mengaitkan dengan penggunaan bilangan dalam kehidupan sehari-sehari secara faktual yang kemudian melahirkan nilai-nilai yang berhubungan dengan kemanfaatan dalam kehidupan. Pendekatan irfani dalam materi operasi hitung bilangan kaitannya dengan prinsip bersodaqoh dalam Islam yaitu peserta didik dapat memetik nilai bahwa, dengan bersodaqoh manusia dapat: menumbuhkan rasa solidaritas, menyehatkan badan/rohani, mengajarkan bersikap rendah hati, dimudahkan rezekinya, dijauhkan dari marabahaya, dilipatgandakan pahalanya oleh Allah swt. dan lain masih banyak manfaat lainnya. Peserta didik juga memahami ganjaran/balasan bagi orang yang tidak mau bersodaqoh/berbagi seperti: dimasukan ke dalam neraka, tidak disukai oleh teman, mudah terkena penyakit, dan lain sebagainya.

Disamping itu, dengan mengaitkan antara operasi hitungan bilangan di sekolah dan ayat-ayat Al-Qur'a pada peserta didik, maka peserta didik akan terbiasa berpikir yang komplit baik dalam hal ilmu pengetahuan umum maupun dalam lingkup spiritual keagamaan. Kehadiran matematika dalam integrasi Islam sangat mendukung peserta didik itu sendiri tentang bagaimana menyatukan matematika dengan agamanya, seperti yang dicontohkan dalam ayat-ayat tentang makna bersodaqoh.

Guru bisa menjelaskan kepada peserta didik tentang hakikat dan tujuan sodaqoh, dimana ketika seseorang mau berbagi (pembagian) terhadap sesama, memang saat itu secara 
kasat mata kalau harta yang dikeluarkan oleh seseorang tidaklah berkurang (pengurangan), akan tetapi harta tersebut malah bertambah (penjumlahan) dan bahkan semua amalan itu akan dibayar oelh Allah swt. Dengan pahala yang berlipat ganda atau dikalikan (perkalian).

Dalam pembelajaran setiap hari baik guru maupun peserta didik, semuanya akan berawal dan berakhir dengan jadwal ataupun waktu yang telah ditentukan oleh sekolah, sehingga disinilah peran guru dalam menerapkan tentang penggunaan waktu (jam) dan sebelum peserta didik dipulangkan agar melakukan pembiasaan dengan melakukan sholat bersama, dalam hal ini guru bisa mengaitkan dengan QS. An-Nissa': 103 berikut:

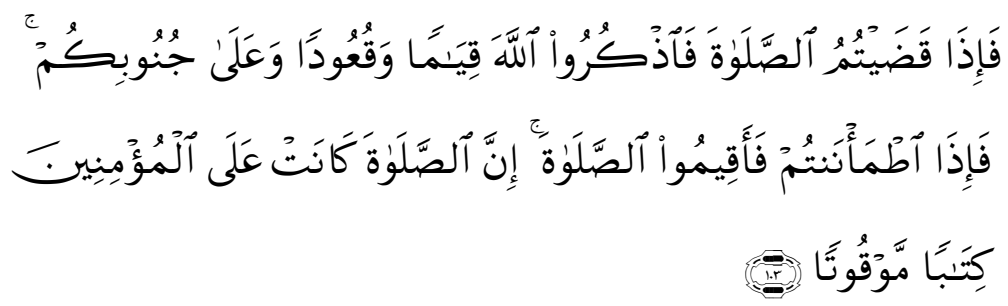

Terjemahan :

Maka apabila kamu telah menyelesaikan shalat(mu), ingatlah Allah di waktu berdiri, di waktu duduk dan di waktu berbaring. kemudian apabila kamu telah merasa aman, Maka dirikanlah shalat itu (sebagaimana biasa). Sesungguhnya shalat itu adalah fardhu yang ditentukan waktunya atas orang-orang yang beriman.

Agar pendekatan bayani, burhani, dan irfani dapat terlaksana dengan baik sesuai rencana pelaksanaan pembelajaran (RPP), maka, guru perlu juga mengadopsi pendekatan dalam pelajarn umum (matematika) yang sesui dengan apa yang tertera dalam RPP. Adapun pendekatan yang digunakan adalah pendekatan saintifik, yang mana dalam kegiatan pembelajarannya terdiri dari:

a. Mengamati

Kegiatan mengamati merupakan kegiatan awal peserta didik dalam melakukan observasi tentang objek yang ingin diteliti baik dalam bentuk kelompok maupun perorangan dengan tujuan agar peserta didik dapat bekerja mandiri ataupun kelompok serta menjawab rasa ingin tahu mereka terhadap objek yang diamati/diteliti baik berupa alam sekita maupun media belajar lainnya. Dalam hal ini peserta didik lebih bisa dekat dengan objek secara langsung karen memang kegiatan ini pemanfaatan akan alat indera sangatlah perlu (mata, telinga, hidung, kulit ataupu lidah).

b. Menanya

Pada fase ini, setelah peserta didik melakukan pengamatan terhadap objek yang diteliti tersebut di atas, maka peserta didik akan diberikan beberapa pertanyaan, yang tentunya pertanyaan-pertanyaan itu tidak lain yakni tentang apa yang telah mereka amati sebelumnya. Tujuan daripada kegiatan menanya adalah agar peserta didik mampu berbahasa dengan baik, 
melatih keberanian untuk tampil sekaligus menjawab dari apa yang mereka belum paham terhadap objek yang mereka teliti.

c. Mengumpulkan informasi

Pada kegiatan mengamati tersebut, peserta didik disuruh mengumpulkan informasi sebanyak-sebanyaknya terkait apa yang mereka amati/teliti, baik berupa uraikan uraikan maupun berupa data/bilangan dan itu tergantung apa objek yang diteliti, dan sebelum informasi itu disampaikan biasanya informasi akan diolah terlebih dahulu, ini dimaksudkan agar informasi yang mereka dapat benar-benar valid dan sesuai dengan apa yang dicari.

d. Mengasosiasi

Disini peserta didik akan dikelompokkan kedalam beberapa kelompok dan mendiskusikan tentang informasi apa yang telah mereka dapat pada saat kegiatan mengamati sebelumnya, lalu mereka akan menyatukan berbagai sumber atau informasi yang mereka dapat dengan kelompak lain.

e. Mengkomunikasikan

Kegiatan ini adalah kegiatan akhir daripada seluruh kegiatan di atas, dimana peserta didik akan menyampaikan tentang apa saja yang mereka dapat terkait dengan apa yang mereka amati tadi, baik berupa ringkasan, gambar, maupun hasil karya lainnya dan disini akan ada penguatan terhadap materi yang mereka pelajari yang tentunya dibantu oleh guru serta bersama-sama mampu menyimpulkan tentang hasil yang ingin dicapai. 


\section{DAFTAR PUSTAKA}

Abdul Raiz. Bulangan Bulat: Teori Bilangan, https:// abdulraiz-raish. blogspot. com/ 2015/ 01/ bilangan-bulat-teori-bilangan.html.

Abdussakir. Matematika 1: Kajian Integratif Matematika dan Al-Qur'an. Malang: UIN Malang Press.

Al Minhaj Syarh Shahih Muslim. 16/141, Dar Ihya' At Turots Al 'Arobi. cet. Ke II. 1392.

Ali M dan Luluk Y. R., PAradigma Pendidikan Universal di Era Modern dan Post-Modern; Mencarai "Visi Baru" atas "Realitas Baru" Pendidikan Kita. 2004.

Andi Prastowo. Pengembangan Bahan Ajar Tematik: Tinjauan Teoritis dan Praktik. Jakarta: Kencana Prenadamedia Group. 2014.

Arso, dkk. Modul Pendidikan Matematika 1. Jakarta: Universitas Terbuka. 2004.

Depdiknas. Strategi Pembelajaran yang Mengaktifkan Siswa. Jakarta: Depdiknas. tt.

Desmita. Psikologi Perkembangan Peserta Didik. Bandung: PT. Remaja Rosda Karya. 2015.

Fadhil darmawi, Makalah Matematika Bilangan, https:// fadhildarmawi. blogspot. com/ 2014/ 06/ makalah-matematika-bilangan.html.

Hollands, Roy. Kamus Matematika. Jakarta: Erlangga 1995.

Joice, Bruce, Marhsa Weil, dan Emily Calhoun. Models of Teaching:Model-model Pengajaran. cet. VIII. Yogyakarta: Pustaka Pelajar. 2009.

Muassasah Qurthubah, Tafsir Al Qur'an Al 'Azhim, Ibnu Katsir, Tafsir surat Al Hadiid ayat 1113/414-415, Riwayat ini adalah riwayat yang shahih.

Rusman. Model-Model Pembelajaran: Mengembangkan Profesioanlisme Guru. Jakarta: PT. Raja Grafindo Persada.

Trianto. Model Pembelajaran Terpadu. Jakarta: Bumi Aksara. 2011.

Yohanes Surya. Teori Bilangan: Seri Olimpiade Sains dan Matematika SD/MI. Jakarta: PT. Kandel. 2016. 